\title{
The colour analysis method applied to homogeneous rocks
}

\author{
Amadé Halász , Ákos Halmai \\ Faculty of Sciences, University of Pécs, Ifjúság u. 6, 7624 Pécs, Hungary \\ "corresponding author, e-mail: tade@gamma.ttk.pte.hu
}

\begin{abstract}
Computer-aided colour analysis can facilitate cyclostratigraphic studies. Here we report on a case study involving the development of a digital colour analysis method for examination of the Boda Claystone Formation which is the most suitable in Hungary for the disposal of high-level radioactive waste. Rock type colours are reddish brown or brownish red, or any shade between brown and red. The method presented here could be used to differentiate similar colours and to identify gradual transitions between these; the latter are of great importance in a cyclostratigraphic analysis of the succession. Geophysical well-logging has demonstrated the existence of characteristic cyclic units, as detected by colour and natural gamma. Based on our research, colour, natural gamma and lithology correlate well. For core Ib-4, these features reveal the presence of orderly cycles with thicknesses of roughly 0.64 to 13 metres. Once the core has been scanned, this is a time- and cost-effective method.
\end{abstract}

Keywords: radioactive waste, claystone, ImageJ, PAST, cyclostratigraphy, Hungary

\section{Introduction}

The most commonly used analytical "tools" of the geologist is his or her own eyes. Yet, at times, our visual analysis of rocks or other natural materials is not precise enough to describe them adequately. Form and texture of things can easily be recognised by us, but colours are much more equivocal. Our sense of colour depends on light, the surrounding environment, the actual state of the atmosphere as well as on personal settings. The human eye performs extremely badly when asked to distinguish between slightly different colours on a larger scale. If we have to differentiate between two closely similar colours, we tend to compare them. But, for example, in the case of a geological core sample we cannot compare the samples on account of the linear extent of the core. Thus, a geologist could describe an entire core without realising that the top of the core contained e.g. $2 \%$ more reddish tone than the bottom. However, slight, visually almost indistinguishable fluctuations could indicate meaningful changes or trends in the former depositional environment (facies changes, clay content and grain size).

The present paper describes a digital analysis technique which can recognise and quantify these fine changes. Colour analysis does not require expensive equipment. Interpretations can be made by computer-aided image analysis (Klimešová \& Ocelíková, 2011) once the core has been scanned. There are also possibilities for image analysis to be used in coal geology (Verhelst et al., 1996) and glacial studies (Malone et al., 2013), fields in both of which colour inhomogeneity is close to that recorded for the Boda Claystone.

The Boda Claystone Formation (BCF) is one of potential host rocks for high-level radioactive waste disposal (Hámos et al., 1996; Konrád, 1999; Konrád \& Hámos, 2006). Previously, it was described as the "most homogeneous formation of Hungary" (Jámbor, 1964), which is why it was chosen for this 
case study. An important point in assessing suitability is the homogeneity of the sequence. Although the buildup of this thick succession used to be described as unvaried and homogeneous, it is in fact composed of four distinct lithological types (Hámos et al., 1999), which provide an opportunity for cycle analysis on the basis of colour. The colour range is between brown and red. The main problem is the reddish brown-brownish red transition, which is barely recognisable by the naked eye; however, it probably does have a geological meaning. In the case of the Boda Claystone, clay content is the main factor which probably allows the method to work. For instance, the upper part of the formation has a higher clay content than the lower (Máthé, 1999) and colour becomes more reddish up-section. Data on clay content are essential in assessments of homogeneity. The very few greyish-green, reduced intercalations suggest climatic events with more precipitation (as described, for example, from the Middle Permian succession in France; Schneider et al., 2006) and/or the ponding of water.

The formation cannot be dated exactly, which explains why some the "classic" investigations cannot be carried out (Weedon, 2003). Flora and fauna useful for dating are absent, which is why the time frame of accumulation of cycles/rhythms cannot be determined, leaving only estimates. In view of the dating problem, samples were collected by depth (depth series analysis; compare Priestly, 1981; Schwarzacher, 1975). In some cases, playa sedimentation was modulated by climate rhythms induced by quasi-periodic changes in the Earth's orbital parameters (e.g., Hofmann et al., 2000; Reinhardt \& Ricken, 2000, Vollmer et al., 2008).

\section{Geological background}

The $\mathrm{BCF}$ was deposited in a rifting basin on the southern margin of Europe during the Permian. An intramontane basin developed, with playa lakes and under arid climatic conditions (Varga et al., 2005; Konrád et al., 2010). Subsidence and basin formation were driven by crustal reorganisation and re-equilibration, following the compressional phases of Variscan orogeny (Vozárová et al., 2009). The surroundings of the playa basin had a moderate relief, a consequence of long-lived denudation of the crystalline basement (Konrád et al., 2010). Correlation with areas forming part of the European platform is hindered by the fact that the controlling processes of the post-orogenic evolution of the Variscan fold-and-thrust belt were very different from those in the foreland basins (McCann et al., 2008).
Therefore, the impact of tectonics on these areas will be difficult to compare. However, sedimentary features of the BCF indicate the same climate aridification of Pangaea as do other Middle Permian playa sediments that formed in isolated intramontane basins along the Variscan foreland (e.g., Lodève Basin; Schneider et al., 2006).

Today, the formation can be studied in the Mecsek Mountains (southwest Hungary), which are part of the Tisza Unit (Haas \& Péró, 2004). The unit comprises three main units (Konrád, 1999), as follows:

- a lower transitional sandstone, 100-150 m thick, characterised by fine-grained sandstone beds;

- a 350-450-m-thick middle albitic claystone/ siltstone with sandstone beds, characterised by $\mathrm{cm}$ - to $\mathrm{dm}$-thick micaceous siltstone and finegrained sandstone intercalations;

- an upper claystone/albitic clayey siltstone/silty claystone unit, with an overall thickness of 400$500 \mathrm{~m}$, with dolomite and siltstone beds showing desiccation cracks.

The dominant component of the formation is brownish-red (silty) claystone and the most important differences between rock types are linked to the clay and albite content (Varga et al., 2005).

The present study focuses on the Ib-4 core (approximately $200 \mathrm{~m}$ in length; sponsored by PURAM and drilled by Rotaqua Ltd), for which the intricate geophysical logging was carried out by Geo-Log Ltd. A detailed geological description of the BCF in this well was provided by Sebe \& Sámson (2006). The cored part of the formation is dominated by silty claystone and clayey siltstone, the lower $60 \mathrm{~m}$ consisting mostly of fine-grained sandstone. The total gamma radiation generally increases upwards in the succession, reflecting a downward increase in grain size. This shows there is a strong correlation between gamma-ray log and lithology (Halász, 2009).

\section{Material and methods}

\subsection{Image acquisition}

Scanned images of core samples from borehole Ib-4 were our input data. The cores were stored under controlled moisture conditions because of the swelling clay minerals. Thus, the humidity of the cores was equal during the scanning process; otherwise this might have caused colour variation of the cores. Core roughness could also influence the analysis, but according to Darvas et al. (2010) there were no major anomalies during the drill- 


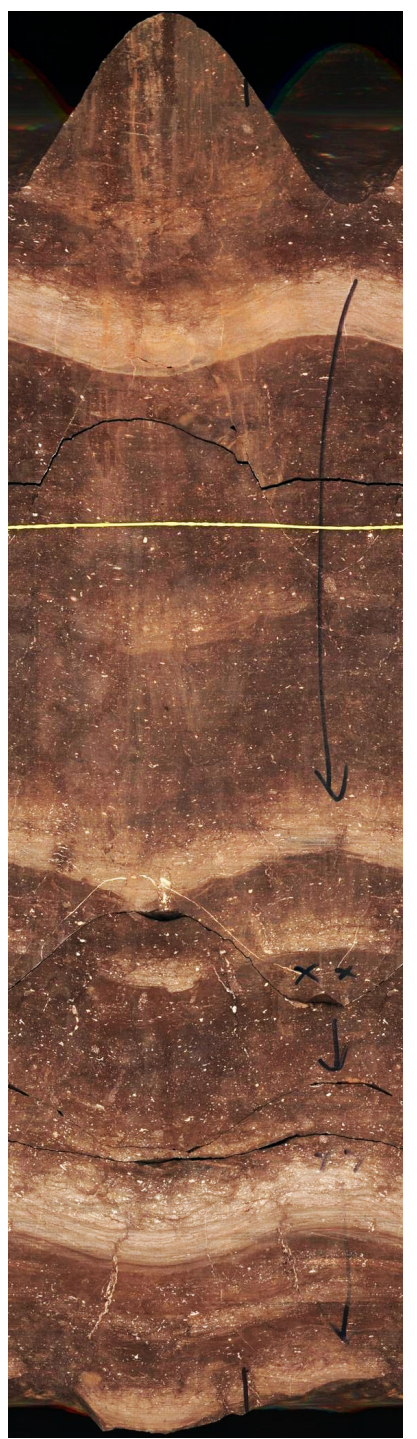

Fig. 1. Scanned image of borehole Ib-4 (647.44-646.85 m) with the arrow on the core pointing downwards. The yellow line is an elastic band which is intended to stabilise the fractured core

ing process that could have had an impact on core roughness. Images were prepared using an "ImaGeo" core sample scanner, based on a rotator- and a sensor-system. The rotator turns the core sample around its long axis. During the rotation the sensor maps the outer hull of the core (for a full technical description, see Maros \& Pásztor, 2001). The spatial resolution of the sensor is approximately $326 \mathrm{dpi}$ in both directions. The output format of the scanner is an uncompressed TIFF image with 24 bits/pixel colour depth. Each TIFF file contains a piece of the core sample (either broken or cut, for technical reasons). The file name includes the start and end values measured in metres from the starting point of the borehole. Each file contains some extra black areas on both sides because of the irregular fracture of samples (Fig. 1).

In order to do a colour analysis, we first had to determine the minimum colour inhomogeneity that allows us to carry out the investigation in the first place. To express or measure the "minimum inhomogeneity" needed to accomplish a successful colour analysis is quite difficult. Naturally, the minimum inhomogeneity depends of colour diversity of the scanned material, spatial distribution of this diversity (soft, long-range transitions or sharp, abrupt colour changes), rock texture, colour and size of embedded grains, but also of shape and size of the sampling window and the number of "bins" used during data aggregation. Generally speaking, the inhomogeneity is "sufficient" as long as the peaks remain above the significance lines ("white noise" lines) of the Lomb periodogram (90-95\%).

\subsection{Colour analysis}

Our first goal was to detect rock changes and cycles that are invisible to the human eye. To address this, we wrote a small ImageJ macro. First, the macro cuts the unnecessary black parts of the image mentioned above, and then splits it into three separate colour channels (R-G-B; 0-255). Finally, the macro cuts the file into 0.1-m-long pieces (based on current dpi). We built histograms with 32 buckets ( 8 units wide) for each piece in each colour channel. If sample size was not divisable by $0.1 \mathrm{~m}$, calculations were made on the available size and an exclamation mark was added to the last value so as to denote non-equal sampling.

We chose the 0.1-m-sampling size for the following reasons:

1. Sampling size is not arbitrary; if too large an offset would be chosen, meaningful changes in sedimentary rock could not be caught because of too "long" averaging. If too small, greatly fluctuating data would be the result. Following empirical spatial diversity checks of the BCF, this offset value must be between 0.1-0.5 metres.

2. The typical sampling interval in borehole geophysics is between 0.1 and 0.2 metres; thus, by using $0.1 \mathrm{~m}$, visual images of the sample and geophysical values measured in the borehole can be compared seamlessly.

Finally, we imported the values into a PAST version 2.17c (Hammer et al., 2001), and selected the most numerous categories in the colour channels. Based on this selection we used the PAST's Lomb periodogram to estimate the colour-based cycles within the succession. 
In this process we could extract several peaks above the 0.01- and the 0.05-significance levels (white noise lines) from the periodogram. There are no reliable readings below these levels. In our earlier studies (Halmai \& Halász, 2011), we had only a single cycle which was above these levels, in part due to erroneous sample sizes and technique.

The most suitable colour channel is the red one because of the distinctive brownish-red colour of the BCF. Data obtained from the red channel describe the fluctuation of the "main" colour. The green channel yields good results as well. Together, the green and red channels describe the secondary, brown, colour of the core. Red and brown are opposites: if the core becomes redder, it is less brown in colour. The third, blue, channel has poor statistical characteristics. The core has no blue or blue-related components. This channel expresses merely lightening or darkening along the core.

We tried to enhance our research by using texture analysis of the $\mathrm{BCF}$, but on account of the textural similarity of sandstones and dolomitic siltstones and the disturbing effect of embedded albitic grains we had to skip this technique. We also attempted some other or mixed image classification methods (algorithms from remote sensing and GIS), yielding moderate results, as described by Halmai \& Halász (2011).

\subsection{Natural gamma analysis}

Since Th, $\mathrm{U}$ and $\mathrm{K}$ are generally concentrated in clay, natural gamma radioactivity of a deposit is one of the most reliable clay indicators (Ma-

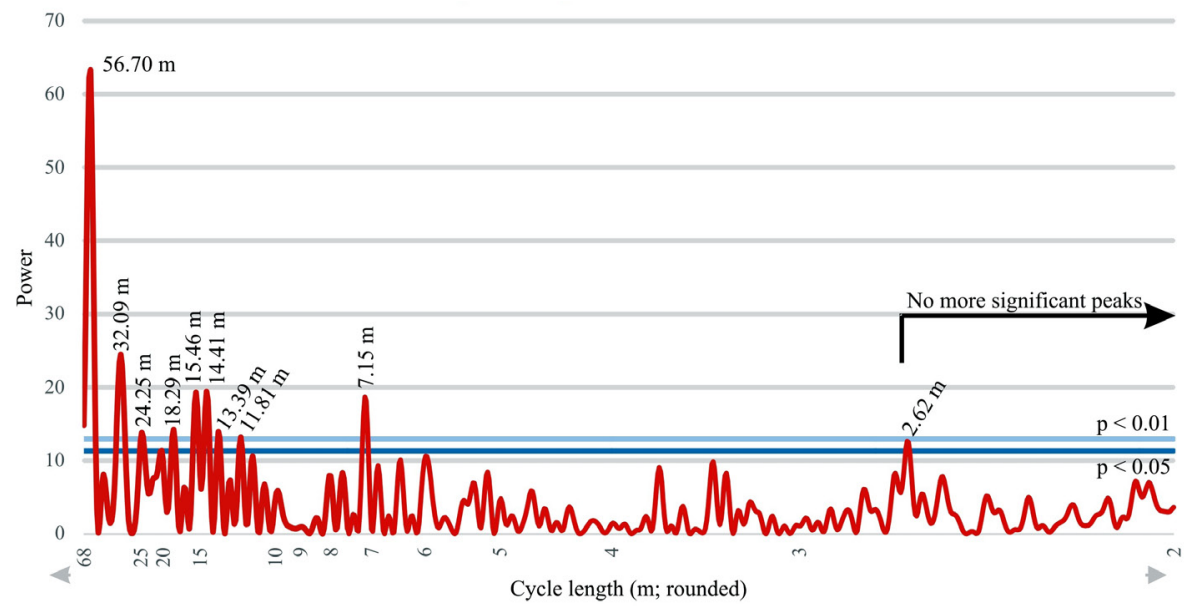

Fig. 2. Modified visual output of the PAST's Lomb periodogram for unevenly sampled data of the red channel (sampling interval $\leq 0.1 \mathrm{~m}$ )

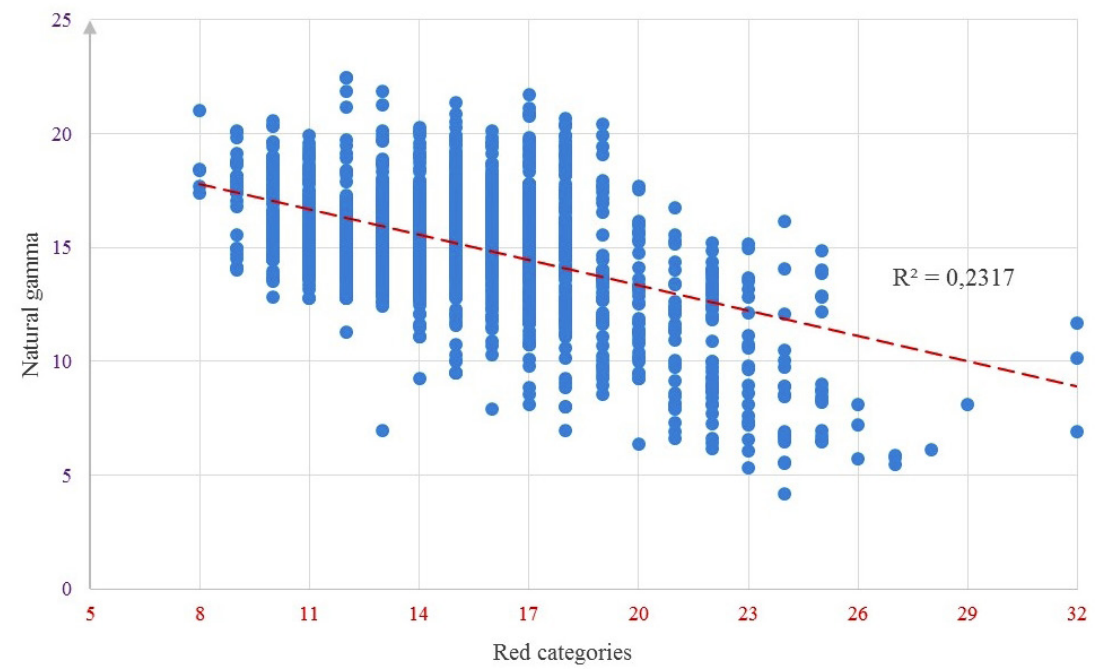

Fig. 3. The pairwise cross plot of natural gamma and red values. The data points are organised into columns on account of discrete categories of colour (32 buckets). The number of data points is 2,104 
rett, 1978). Application of gamma ray permits the determination of particle size distribution within a succession. Following studies by Szarka et al. (2003), there is a strong correlation between the natural gamma value and the illite rate in percentage. Therefore it is possible to calculate the illite content by using natural gamma values. As determined by Varga et al. (2006), the illite/muscovite content in claystones are greater than in albitolites, siltstones and sandstones; this confirms the outcome of the study by Szarka et al. (2003). The well-known uranium anomaly (Barabás \& Barabásné Stuhl, 1998) can affect measurements in the West Mecsek Mountains, and zircon enrichment can also influence natural gamma results (Hurley \& Faribau, 1957). Calibration of clay content and gamma ray signal was performed by Maros et al. (2008, p. 138) for the BCF, showing a "close correlation between $\mathrm{K}_{2} \mathrm{O}$ content and natural gamma".

The total gamma radiation generally increases up-section, reflecting a downward increase in grain size. This shows that there is a strong correlation between gamma-ray log and lithology. Geophysical well logs have proved the existence of characteristic cyclic units that had been detected by other methods and documented thicknesses of cycles comprised in them. Where thick homogeneous siltstone and silty claystone formed, the natural gamma is useful for subdivision of sequences. In such sections the natural gamma log shows a spectacular cyclical pattern (Halász, 2012).

Halász (2012) also recorded cyclicity in clay content within the present formation. Based on natural gamma and resistance values, he defined previously unknown cycles of overall thicknesses between 7 and $12 \mathrm{~m}$. We could apply this to units considered to be homogeneous; thus, natural gamma values can be used in the cycle-stratigraphic analysis of the formation.

\section{Results}

\subsection{Cyclicity based on colour analysis}

Our visual examination of the lithology indicated the presence of cyclicity on different scales. Based on the present borehole, we defined cycles and rhythms typical of the formation. As a first step, we examined the entire succession during colour analysis and determined thicknesses of the rhythms. The results are illustrated in Fig. 2. The units of the lower 'Frequency' axis denote lengths of cycles or rhythms expressed in $1 / \mathrm{N}$ metres format, where $\mathrm{N}$ is the given value on the axis, e.g., the value of " 0.4 " has to be interpreted as $1 / 0.4=2.5 \mathrm{~m}$. The left 'Power' axis is in units proportional to the square of the amplitudes of the sinusoids present in the data. The 0.01 and 0.05 significance levels are marked as red dashed lines. There are no reliable peaks under these lines.

The thickness of the cycles (based on red channel) varies between $2.62 \mathrm{~m}$ and $56.7 \mathrm{~m}$. We selected data from above the significance level only. The sampled core contains the 2.6-m-cycle which corresponds to the centimetre- and metre-scale couplets of dolomite and claystone beds observed in most of the outcrops and cores. The centimetre-scale dolomite beds are arranged into bundles. The 56.70-m-thick cycle deserves special attention. It can be interesting in the case of radioactive waste repository design. By means of cycle stratigraphic studies we were able to augment our knowledge of the homogeneity of the formation, but only vertical tendencies can be characterised at present.

The green and blue values show nearly the same cycles as the red value, yet with lower statistical reliability. Below the significance levels we found two additional rhythms; the 1.3- and 1-m-thick cycle. The first is comparable with natural gamma value, the second corresponds to lithology.

\subsection{Lithology, colour and natural gamma}

The natural gamma values are also suited for statistical and depth series analyses. As shown in Fig. 3, correlation between natural gamma and colour-based cyclicity calculation is considerably strong $(\mathrm{R} \approx-0.481383 ; \mathrm{N}=2104$, significance level is $<0.0001)$, which suggests that colour could be related to clay content and thus to grain size.

Halász (2009) carried out a statistical analysis of cycle thickness based on the traditional lithological description. As shown in Table 1, values for cycle thicknesses obtained by different methods

Table 1. Typical and average cycle thicknesses resulting from different methods compared to previous results

\begin{tabular}{lcccccc}
\multicolumn{1}{c}{ Cyclicity estimated from } & Average thickness [m] & \multicolumn{5}{c}{ Typical cycle thickness [m] } \\
\hline Previous results (Halász, 2009) & - & $\cong 7$ & $\cong 2.5$ & $\cong 1.2$ & $\cong 1.0$ & $\cong 0.5$ \\
Lithology & 13.8 & 7.2 & 2.4 & 1.2 & 0.97 & 0.64 \\
Natural gamma & 12.5 & 7 & 2.6 & 1.4 & - & - \\
Colour (red channel) & $11.80 / 13.39$ & 7.15 & 2.62 & 1.34 & 1 & - \\
\hline
\end{tabular}


are well comparable. As is clear from small- and medium-scale cycle analysis, there is a good correlation between lithology, natural gamma and colour-based results.

\section{Conclusions}

By means of the present studies, we have augmented our knowledge of the homogeneity of the BCF, which is built up of 60-150-m-thick units, which are homogeneous as far as (radioactive waste repository) isolation properties are concerned. When choosing potential host rocks for radioactive waste disposal, the primary criterion is vertical and horizontal homogeneity. In spite of internal inhomogeneities, on a geological scale (or with a view of establishing disposal facilities) the formation can be considered to be vertically homogeneous. However, further studies are needed to evaluate horizontal homogeneity.

Data previously obtained from other methods indicate that colour data can be used as a proxy for clay content and grain size within the BCF. There is a good correlation between colour, natural gamma and lithology. The benefits of using colour analysis are time and costs. Once the core is scanned, the measurement can be done in front of the computer in a couple of hours, depending of core length. Control measurements can be done at any time, with any appropriate software without extra cost. There are several potential applications of our research for the BCF. The colour analysis could be used to complement other tools (e.g., geophysical logs, lithological logs) used in high-resolution stratigraphic correlation. It could also be a fast and cost-effective, pre-evaluation technique prior to analysis using traditional methods.

Results of spectral analyses of all colour, lithology and natural gamma data from core $\mathrm{Ib}-4$ reveal the presence of orderly cycles with thicknesses of roughly 0.64 to 13 metres. Based on cycle wave length ratios, we may suggest that these regular cycles and rhythms reflect perturbations in climate induced by Milanković orbital cycles. Because of a lack of chronostratigraphic dates we could only calculate with the ratio of thicknesses. Following suggestions made by Blatt et al. (1991), the Milanković orbital cycles ratio appears to be present in our data. Based on that approximately $1 / 2 / 4.8$ ratio we presume that the 1.4-, 2.6- and 7-m-thick cycles were induced by Milanković orbital cycles.

\section{Acknowledgements}

A major part of the present study was carried out for the Public Agency for Radioactive Waste Management (PURAM) as part of the Boda Claystone Research Programme.

\section{References}

Barabás, A. \& Barabásné, Stuhl, Á., 1998. A Mecsek és környéke perm képződményeinek rétegtana [Stratigraphy of Permian formations of the Mecsek Mts and their surroundings] In: Bérczi I. \& Jámbor, Á. (Eds), Magyarország képződményeinek rétegtana [Stratigraphy of Hungarian formations]. MOL Rt. - MÁFI, Budapest, 187-215 [in Hungarian]

Blatt, H., Berry, W.B.N. \& Brande, S., 1991. Principles of stratigraphic analysis. Blackwell Scientific, Boston, 308 pp.

Darvas, K., Ludmann, L., Rőczei, N. \& Szegő, I., 2010. Az Ib-4 jelü mélyfúrás lemélyített szakaszáról fúrásmüszaki záródokumentáció [Borehole Ib-4 Drilling Engineering Report]. Golder Associates, Pécs, 756 pp.

Haas, J. \& Péró, Cs., 2004. Mesozoic evolution of the Tisza Mega-unit. International Journal of Earth Sciences 93, 297-313.

Halász, A., 2009. Cycles and rhythms within the Boda Claystone in the borehole Ib-4. Central European Geology $52,325-342$.

Halász, A., 2012. A Bodai Agyagkő Formáció ciklusos felépítése lyukgeofizikai szelvények alapján [Cyclostratigraphic analysis of the Boda Claystone Formatian using borehole logging data] Magyar Geofizika 53, 110-120 [in Hungarian]

Halmai, A. \& Halász, A., 2011. Colour Analysis of the Boda Claystone Formation in Borehole Ib-4 XIV. Congress of Hungarian Geomathematics, Abstract CD.

Hammer, Ø., Harper, D.A.T. \& Ryan, P.D., 2001. PAST: Paleontological statistics software package for education and data analysis. Palaeontologia Electronica 4, (1), $9 \mathrm{p}$.

Hámos, G., Majoros, Gy. \& Máthé, Z., 1996. The geology of Boda site, Hungary Surface and URL based investigations. TOPSEAL '96 Transactions, Stockholm, vol. 2, 196-199.

Hámos, G., Földing, G., Majoros, Gy. \& Konrád Gy., 1999. The role of geological research in the qualification program of the Boda Claystone Formation. 'The Geology of Today for Tomorrow'. A satellite conference of the World Conference of Science, Budapest. 76-84.

Hofmann, A., Tourani, A. \& Gaupp, R., 2000. Cyclicity of Triassic to Lower Jurassic continental red beds of the Argana Valley, Morocco: implications for palaeoclimate and basin evolution. Palaeogeography, Palaeoclimatology, Palaeoecology 161, 229-266.

Hurley, P.M. \& Faribau, H.W., 1957. Abundance and distribution of uranium and thorium in zircon, sphene, apatite, epidote and monazite in granite rocks. Transaction American Geophysical Union, 38 p. 
Jámbor, Á., 1964. A Mecsek hegység alsó permi képződményei [Lower-Permian formations of the Mecsek Mts]. Mecsekérc Ltd. Archives, Kővágószólős, 113 pp. [in Hungarian]

Klimešová, D. \& Ocelíková, E., 2011. GIS and Image Processing. International Journal of Mathematical Models and Methods in Applied Sciences 5, 915-922.

Konrád, Gy., 1999. The Boda Claystone Formation. 'The Geology of Today for Tomorrow'. A satellite conference of the World Conference of Science, Budapest. Excursion Guide Book, 65-75.

Konrád, Gy. \& Hámos, G, 2006. A magyarországi nagy aktivitású radioaktív hulladéktároló telephely kijelölésének földtani szempontjai és az eddigi kutatások eredményei [Geological aspects and results of the previous research, of the high-level radioactive waste repository site in Hungary]. Acta Geographica, Geologica et Meteorologica Debrecina 1, 33-39 [in Hungarian]

Konrád, Gy., Sebe, K., Halász, A. \& Babinszki, E., 2010. Sedimentology of a Permian playa lake: Boda Claystone Formation, Hungary. Geologos 16, 27-41.

Malone, T., Hubbard, B., Merton-Lyn, D. \& Worthington, P., 2013. Borehole and Ice Feature Annotation Tool (BIFAT): A program for the automatic and manual annotation of glacier borehole images. Computer $\mathcal{E}$ Geosciences 51, 381-389.

Marett, G., 1978. Clay content determination by natural gamma ray spectrometry. US Patent US4096385 A.

Maros, Gy. \& Pásztor, Sz., 2001. New and orientated core evaluation method: ImaGeo. European Geologist 12, 40-43.

Maros, Gy., Andrássy, L., Zilahi-Sebess, L. \& Máthé, Z. 2008. Modelling the Boda Aleurolite Formation (BAF) based on core analyses using laser-induced plasma spectrometer ImaGeo-LIPS. First break 26, 129-139.

Máthé, Z. (Ed.), 1999. Ásvány-kőzettani, kőzetgeokémiai és izotóptranszport vizsgálatok. [Mineralogical, petrographical, rock geochemical and isotope transport studies]. Final report of the Short-term Investigation Program of the Boda Siltstone Formation 4, Mecsekérc Ltd. Archives, Pécs, 153 pp.

McCann, T., Kiersnowski, H., Krainer, K., Vozárová, A., Peryt, T., Oplustil, S., Stollhofen, H., Schneider, J., Wetzel, A. \& Boulvain, F., 2008. Permian. In: McCann, T. (Ed.). The Geology of Central Europe, vol. 1. Precambrian and Paleozoic. Geological Society, London, 531-598.

Priestly, M.B., 1981. Spectral Analysis and Time Series. Academic Press, London. 890 p.

Reinhardt, L. \& Ricken, W., 2000. The stratigraphic and geochemical record of Playa Cycles: monitoring a Pangaean monsoon-like system (Triassic, Middle
Keuper, S Germany), Palaeogeography, Palaeoclimatology, Palaeoecology 161, 205-227.

Schneider, J., Körner, F., Roscher, M. \& Kroner, U., 2006. Permian climate development in the northern peri-Tethys area - the Lodève basin, French Massif Central, compared in a European and global context. Palaeogeography, Palaeoclimatology, Palaeoecology 240, 161-183.

Schwarzacher, W., 1975. Sedimentation Models and Quantitative Stratigraphy. Elsevier, Amsterdam. 298-299.

Sebe, K. \& Sámson, M., 2006. Ib-4 fúrás Bodai Aleurolit Formáció [Borehole Ib-4 Boda Claystone Formation report]. Mecsekérc Ltd. Archives, Pécs, 16 pp. [in Hungarian]

Szarka, R., Kollár, L., Majoros, Gy. \& Lovas, A., 2003. A BAF-ra mélyült archív fúrások geológiai és mélyfúrás-geofizikai adatainak egységes feldolgozása. [Uniform processing of archive geological and geophysical borehole data of the Boda Claystone Formation.] Mecsekérc Ltd. Adattár, Kővágószőlős, 1-38 [in Hungarian]

Varga, A.R., Szakmány, Gy., Raucsik, B. \& Máthé, Z., 2005. Chemical composition, provenance and early diagenetic processes of playa lake deposits from the Boda Siltstone Formation (Upper Permian), SW Hungary. Acta Geologica Hungarica 48, 49-68.

Varga, A., Raucsik, B., Szakmány, Gy. \& Máté, Z., 2006. A Bodai Aleurolit Formáció törmelékes kőzettípusainak ásványtani, kőzettani és geokémiai jellemzői [Mineralogical, petrological and geochemical characteristics of the siliciclastic rock types of Boda Formation]. Földtani Közlöny 136, 201-231 [in Hungarian]

Verhelst, F., David, P., Fermont, W., Jegers, L. \& Vervoort, A., 1996. Correlation of 3D-computerized tomographic scans and 2D-colour image analysis of Westphalian coal by means of multivariate statistics. International Journal of Coal Geology 29, 1-21.

Vollmer, T., Werner, R., Weber, M., Tougiannidis, N., Röhling, H G. \& Hambach, U., 2008. Orbital control on Upper Triassic Playa cycles of the Steinmergel-Keuper (Norian): A new concept for ancient playa cycles. Palaeogeography, Palaeoclimatology, Palaeoecology 267, 1-16.

Vozárová, A., Ebner, F., Kovács, S., Kräutner, H-G., Szederkényi, T., Kristić, B., Sremac, J., Aljinovič, D., Novak, M. \& Skaberne, D., 2009. Late Variscan (Carboniferous to Permian) environments in the Circum Pannonian Region. Geologica Carpathica 60, 71-104.

Weedon, G., 2003. Time-series analysis and cyclostratigraphy. Cambridge University Press, Cambridge. 259. pp.

Manuscript received: 3 November 2014 Revision accepted: 15 September 2015 